\title{
State Merit Aid Programs and Youth Labor Market Attachment
}

\author{
David E. Frisvold and M. Melinda Pitts
}

Working Paper 2018-4

June 2018

Abstract: This paper examines the impact of state merit-aid programs on the labor market attachment of high school-aged youths. The labor force participation rate of teenagers has fallen substantially in recent decades, coinciding with the introduction of merit-aid programs. These programs reduce the price of attending an in-state public college or university for high-achieving students and have the potential to influence students' allocation of time and effort between labor market activities, human capital development, and other forms of leisure. We examine the influence of these programs based on their generosity, both in the amount of aid provided to a recipient and the percent of students who are recipients of aid, and in their selectivity. Our results suggest that programs that are more selective reduce labor force participation, but are not a significant cause in the decline in teenage labor force participation in recent decades.

JEL classification: J2, I2

Key words: merit aid, labor force participation, education, financial aid

https://doi.org/10.29338/wp2018-4

The authors are grateful to Biplab Datta and Astha Sen for research assistance. They also thank Angela Dills; Amanda Griffith; Hope Corman; seminar participants at the Federal Reserve Bank of New York, University of Iowa, and University of Nebraska; and participants at the South Carolina Applied Micro Day, Southern Economic Association, and Western Economic Association conferences for helpful comments. The views expressed here are the authors' and not necessarily those of the Federal Reserve Bank of Atlanta or the Federal Reserve System. Any remaining errors are the authors' responsibility.

Please address questions regarding content to David Frisvold, University of Iowa, Department of Economics, 21 E. Market Street, Iowa City, IA 52242, 319-335-0957, david-frisvold@uiowa.edu, or M. Melinda Pitts, Federal Reserve Bank of Atlanta, Research Department, 1000 Peachtree Street NE, Atlanta, GA 30309-4470, 404-498-7009, Melinda.pitts@atl.frb.org.

Federal Reserve Bank of Atlanta working papers, including revised versions, are available on the Atlanta Fed's website at www.frbatlanta.org. Click "Publications" and then "Working Papers." To receive e-mail notifications about new papers, use frbatlanta.org/forms/subscribe. 


\section{Introduction}

State merit-aid programs have become an increasingly common form of financial aid for higher education in recent decades. In contrast to need-based aid, these programs provide aid to students who meet specific educational criteria in high school and college and who attend an instate college or university. The design of these programs, and the resulting incentives, have the potential to significantly influence the behavior of high school students by altering the laborleisure decisions of youth. For example, as merit aid programs increase the reward for higher levels of educational achievement during high school, students may increase their time spent on schoolwork and reduce work and/or non-school leisure activities.

Understanding the influence of merit aid programs on labor supply is especially relevant, given that the labor force participation rate (LFP) of youth has substantially decreased relative to the overall LFP of all working-age individuals beginning around 2000. As shown in Figure 1, youth LFP has consistently been lower than the overall rate for all adults ages 16 and over. While the LFP of all adults has declined from 67 to 63 percent from 2000 through 2014, youth LFP declined during this period from 52 to 34 percent. Since 2004, youth LFP was lower than in any previous year dating back to 1960 .

It is important to understand the decline in youth LFP and the policies that may be influencing the decision to participate in the labor market because of the significant influence of the decline in youth LFP on aggregate trends in LFP, even though youths represent a small percentage of the workforce, and because of the potential influence on future productivity (Aaronson, Park, and Sullivan, 2006). The literature on the return to high school work experience generally finds positive effects on adult wages, although these returns have fallen over time (Baum and Ruhm, 2016). The influence of youth LFP on later productivity and labor market activity would depend on whether youths are replacing time spent working with time spent on the development of human capital.

As shown in Figure 2, this decline in youth LFP occurred during the same period as the expansion of state merit-aid programs. The number of state merit-aid programs increased from 3 in 1995 to 13 in 2000 to 19 in 2005 to 23 in 2012 . The potential influence of state merit-aid 
programs on the decline in youth LFP has received relatively little attention, ${ }^{1}$ but Aaronson, Park, and Sullivan (2006) document that youth LFP fell faster in states with merit aid programs than in other states between 2000 and 2004.

Given the similar timing of the increase in merit aid programs and the decline in LFP for teens, this research examines the influence of state merit-aid programs, focusing on the generosity and selectivity of these programs, on the labor supply of teenagers. These measures of the generosity and selectivity of state merit-aid programs vary across states and over time, in contrast with most of the prior research on these programs that focuses on the introduction of a merit-aid program in one state or that treats merit-aid programs as homogenous. In particular, we focus on two measures of generosity: the amount of aid available as a percent of the average in-state tuition and fees and the percent of in-state college students receiving merit aid, and two measures of selectivity: the high school grade point average (GPA) and standardized test score requirements that determine eligibility for the merit-aid scholarship. We construct these measures for all states from 1989 through 2013, which we link with the basic monthly Current Population Survey (CPS) to examine labor force participation, employment, hours worked, and hours worked conditional on employment during the academic year for teenagers ages 16 to 18 .

Although a sizeable literature on merit-aid programs has developed in recent years, our paper makes two important contributions to the literature. First, building upon the descriptive analysis of teen LFP by Aaronson, Park, and Sullivan (2006), our paper provides a comprehensive analysis of the impact of merit-aid programs on the labor supply decisions of teenagers. Second, our paper focuses on the heterogeneity of merit-aid programs, instead of treating all or a subset of programs as equivalent, and examines measures of the generosity and selectivity of merit-aid programs.

To determine the influence of merit-aid programs, we estimate difference-in-differences specifications comparing the changes over time in labor market outcomes of teenagers among states with merit-aid programs and states without these programs. Our results suggest that introducing a merit-aid program that is highly selective, as characterized by a high school GPA requirement of at least 3.5 for students to be eligible, leads to a reduction in teenage LFP of nearly 4 percentage points. However, merit-aid programs increase LFP for plans with low and

\footnotetext{
${ }^{1}$ Other possible explanations for the decline in youth LFP include immigration and welfare reform (Aaronson, Park, and Sullivan, 2006).
} 
moderate levels of generosity and low levels of selectivity. Further, the labor market response occurs on the extensive margin, but not the intensive margin; the estimates for employment are similar to the results for labor force participation and there is little impact of merit-aid programs on hours worked conditional on employment. Overall, the results suggest that different aspects of merit-aid scholarships influence the labor supply decisions of teens, but these programs explain very little of the observed decline in teen LFP in the past two decades.

\section{Background on Merit Aid Programs}

\section{a. Description of Merit Aid Programs}

Since 1988, 25 states have initiated merit-aid programs. The details of the programs vary across states, but generally consist of financial aid available to students who achieved specific accomplishments in high school, such as a minimum GPA or a minimum standardized test score. The financial aid typically can be used to reduce or eliminate the costs of tuition and/or fees at an in-state public institution.

Table 1 displays an overview of each states' merit-aid program. ${ }^{2}$ We define a merit-aid program as one in which the primary eligibility criteria are academic proficiency without a needbased component. For each state that offered a merit-aid program between 1989 and 2013, the table includes the initial and final academic year of the program and the averages across all years of the generosity and selectivity of the state's programs: the maximum amount of aid available for all college expenses as a percent of the average in-state tuition and fees of 4-year public universities, the average percent of in-state college students receiving merit aid, the minimum GPA eligibility requirement, and the minimum standardized test score eligibility requirement. ${ }^{3}$

There is substantial variation in the generosity of merit-aid programs across states, both in the amount of aid provided to a recipient and the percent of students who are recipients of aid. For example, the generosity to recipients varies from 7.0 percent of the average in-state tuition and fees of 4-year public institutions in Illinois to 131.2 percent in Florida. The generosity of the

\footnotetext{
${ }^{2}$ States not listed in Table 1 did not have a merit-aid program between 1989 and 2013. Further details about each state's merit-aid program are available in Appendix Table 1. Prior research has focused on alternate sets of state programs; we document these differences in Appendix Table 2. The generosity measures for each year are shown in Appendix Tables 3 and 4. The sources of information for each program are shown in Appendix Tables 5 and 6.

${ }^{3}$ The standardized test score requirements are shown as ACT scores. Minimum SAT score requirements are converted into ACT equivalents.
} 
programs in terms of providing aid to the greatest percent of college students varies from an average of 0.6 percent in Illinois to 32 percent in Georgia and Kentucky. ${ }^{4}$

The generosity of the programs vary over time as well. Three states have eliminated their merit-aid program, and other states have changed the details of their program over time. For example, Georgia, which is the most widely studied of these programs, reduced the maximum amount of financial aid offered from 113 percent of tuition and fees in 1995-6, which was the first year that the program became universally available, to 73 percent in 2012-13. The percent of college students receiving merit aid in Georgia also fell from 36 percent in 2000 to 27 percent in 2013 .

In addition to their generosity, state programs vary in their eligibility requirements. The most commonly used metrics among state merit-aid programs that measure their selectivity are the minimum high school GPA and the SAT or ACT test score required for a student to be eligible for merit-aid scholarships. Eighteen states offer programs that utilize a minimum high school GPA threshold to determine eligibility, as shown in Table 1. These thresholds vary from 2.5 to 3.5. Sixteen states utilize a minimum standardize test score to determine eligibility. These thresholds vary from 15 to 30, with five programs requiring a score of 20 on the ACT (or the ACT-equivalent on the SAT) in the initial year of the program. Sixteen programs, offered in 13 states, have both a minimum high school GPA requirement and a minimum standardized test score requirement.

\section{b. Why Merit Aid Programs Could Influence Pre-High School Graduation Labor Market Outcomes}

Merit-aid programs reduce the price of college attendance and, thus, have the potential to influence students' allocation of time and effort between labor market activities and human capital development. A key feature of merit-aid programs, as distinct from need-based aid, is that the price reduction depends upon whether the student exceeds specific educational criteria in high school in order to receive the aid. The value of a merit-aid program to a student depends on the probability that a student qualifies for merit aid and the magnitude of the price reduction,

\footnotetext{
${ }^{4}$ As shown in Appendix Figure 1, these two dimensions of the generosity of programs are positively correlated, with states that provide financial aid to a high percentage of students also providing aid that is a high percentage of tuition and fees. A notable exception is Kentucky, which provides support to a high percentage of students but the support covers a modest percentage of tuition and fees.
} 
which motivates our emphasis on the generosity and selectivity of merit-aid programs as the defining characteristics of a program.

The probability that a student qualifies for merit aid depends upon the eligibility criteria for the program and the student's academic credentials. There is some uncertainty for students because their academic credentials at the end of high school (in order to initially qualify for merit aid) are not known when making labor supply decisions. For students who perceive that their probability of receiving merit aid is high, the subsidy reduces the cost of college attendance, which could lower the desire to work during high school to pay for college. Alternatively, for these students, the subsidy could increase labor force participation as students are able to reduce the amount of time studying and are able to work to increase consumption in high school and college. For students who perceive that their probability of receiving merit aid is modest, the opportunity to receive financial aid to lower the cost of college attendance provides a further incentive for these students to devote more time to school activities and less time working. For students with a low perceived probability of receiving merit aid, including students with a low probability of attending college, merit-aid programs are unlikely to influence labor supply decisions except if there is a general equilibrium effect on low-skilled wages. ${ }^{5}$

In states with a merit-aid program that provides aid equal to a high percentage of tuition, fees, and other expenses, the reduction in the price of college attendance is likely to reduce the amount of time spent working. However, in states with less generous programs on this dimension, the influence could be more nuanced. If such programs encourage students to attend college who otherwise might not have attended due to costs and credit constraints, these students might increase their labor supply to earn the difference between the costs of attendance and the value of the merit-aid scholarship. Thus, there is likely to be heterogeneity in the response to merit aid programs, which we investigate in the sections below.

\section{c. Related Literature and the Contribution of this Paper}

\footnotetext{
${ }^{5}$ There is the possibility that merit-aid programs influence the demand for labor of individuals who do not attend college. If these programs increase college attendance, then the pool of individuals who do not attend college will be smaller and more negatively selected. Thus, it could become less desirable for employers to hire high school dropouts and high school graduates after the introduction and expansion of merit-aid programs.
} 
A growing body of literature examines the influence of state merit-aid programs on college attendance, college graduation, and labor market outcomes after college. ${ }^{6}$ The results from this literature generally find that merit-aid programs increase in-state college attendance with mixed evidence on the impacts on overall college attendance and college graduation. Most of this evidence is based on studies of a single state, such as Georgia (Cornwell, Mustard, and Sridhar, 2006), Tennessee (Pallais, 2009), West Virginia (Scott-Clayton, 2011), and Massachusetts (Cohodes and Goodman, 2014). Research that examines multiple states either treats all merit-aid programs as homogenous, provided that they are available to a large portion of high school students in the state (Dynarski 2000, 2004; Conley and Taber, 2011; Fitzpatrick and Jones, 2016), or divides merit-aid programs into two categories (Sjoquist and Winters, 2012, 2015). Our paper contributes to this literature by introducing new measures of generosity that reflect both the breadth and amount of merit-aid scholarships. ${ }^{7}$

Less research examines the influence of state merit-aid programs on students' behavior in high school. Henry and Rubenstein (2002) and Pallais (2009) find that the introduction of meritaid scholarships in Georgia and Tennessee improved student outcomes on standardized tests in high school, likely due to increased effort in school. Aaronson, Park, and Sullivan (2006) document a decline in teen LFP of 1.7 percentage points in states with merit aid programs compared to other states between 2000 and 2004, but the decline in LFP of 18-19 years olds in school is much smaller and there is no change for 18-19 years olds not in school.

There is a sizable literature on the costs and benefits of employment during high school. In general, employment in high school has positive effects on future employment and earnings (e.g., Hotz, Xu, Tienda, and Ahituv, 2002; Light, 2001; Ruhm, 1997). However, Baum and Ruhm (2016) suggest that the positive returns have fallen over time. These studies tend to examine data from the 1979 and 1997 cohorts of the National Longitudinal Study of Youth, which largely predates the decline in teen LFP. For example, the youngest respondents in the NLSY97 would have attended high school through approximately 2003 (Baum and Ruhm, 2014). There is no consensus on the impact of employment on high school educational outcomes, with different papers finding negative, positive, and no impacts of working (e.g., Eckstein and

\footnotetext{
${ }^{6}$ This is distinct from the literature on the effect on need-based financial aid (e.g., Castleman and Long, 2013).

${ }^{7}$ Additionally, research on the institutional responses to merit-aid programs finds that colleges and universities increase tuition and fees (Long, 2004; Griffith, 2011). Our measure of merit aid as a percent of average tuition and fees incorporates these institutional responses.
} 
Wolpin, 1999; Montmarquette, Viennot-Briot, and Dagenais, 2007; Sabia, 2009; Lee and Orazem, 2010).

This paper offers multiple contributions that build upon these literatures. This is the first paper to examine the impact of merit aid programs on teenager's labor market outcomes. We introduce new measures of the generosity and selectivity of merit-aid programs to determine whether there are heterogeneous impacts based on program characteristics. We examine another source of heterogeneity by examining the differential impact of merit aid based on the parents' education, which serves as a proxy for the likelihood that the student would attend college that is determined prior to the student entering high school. Additionally, we examine the labor supply response on both the extensive and intensive margins.

\section{Methodology}

To examine the impact of state merit aid programs on labor market outcomes prior to high school graduation, we compare the changes in these outcomes within states that adopt a merit aid program over time to changes within states that do not adopt a program. We begin by assuming that all merit aid programs are equivalent and estimate the following:

$$
Y_{i s t}=\alpha_{0}+\alpha_{1} \text { Merit }_{s t}+\gamma X_{i s t}+\theta_{s}+\mu_{t}+\varepsilon_{i s t}
$$

where $Y$ denotes the outcome for individual $i$ in state $s$ in year $t$. The outcomes of interest are labor force participation, employment, and hours worked, hours worked conditional on employment, working more than 10 hours per week, and working more than 20 hours per week during the academic year between the ages of 16 and 18; labor force participation is the primary focus throughout the paper. Merit is a binary variable equal to one if a merit-aid program existed in the individual's state of residence at age 18. $X$ is a vector of individual and household characteristics. $\theta$ and $\mu$ represent state and year fixed effects, respectively. $\varepsilon$ denotes a stochastic error term. $\alpha$ and $\gamma$ denotes parameters to be estimated. $\alpha_{1}$, which represents the impact of a merit-aid program, is the parameter of interest.

The above specification is similar to the methodology used in prior, related research, but one limitation is that all state merit-aid programs are treated as equivalent. To address this limitation, Dynarski (2004, 2008) and Fitzpatrick and Jones (2016) define a merit-aid program as 
one in which at least 30 percent of high school students in the state would be eligible to receive merit aid; all other programs are treated as equivalent to not having a program. ${ }^{8}$ Sjoquist and Winters $(2012,2015)$ split the set of merit-aid programs into strong and weak programs. ${ }^{9}$ We replicate the classifications of each of these sets of authors to examine the influence of these alternate definitions on the estimates of the impact of merit-aid programs. ${ }^{10}$ Although these different definitions are useful alternatives to treating all merit-aid programs as equivalent, these measures potentially fail to capture important heterogeneity in merit-aid programs that could influence youth labor market outcomes.

We also examine the generosity and selectivity of merit aid programs and estimate the following:

$$
\begin{aligned}
Y_{i s t}= & \beta_{0}+\beta_{1} \text { Merit }_{s t}+\beta_{2}\left(\text { Merit }_{s t} \times \text { MaxAid }_{s t}\right)+\beta_{3}\left(\text { Merit }_{s t} \times \text { PctReceipients }_{s t}\right)+ \\
& \beta_{4}\left(\text { Merit }_{s t} \times G P A_{s t}\right)+\beta_{5}\left(\text { Merit }_{s t} \times A C T_{s t}\right)+\delta X_{i s t}+\vartheta_{s}+\pi_{t}+\epsilon_{i s t},
\end{aligned}
$$

where MaxAid represents the maximum amount of aid available for all expenses as a percent of the average in-state tuition and fees of 4-year public universities and PctRecipients represents the percent of in-state college students receiving merit aid. ${ }^{11} G P A$ is the minimum GPA requirement and $A C T$ is the minimum ACT test score requirement; each are represented by three indicator variables related to the level required to qualify for merit aid. ${ }^{12}$ All other variables and parameters are defined analogously as in equation (1). These multiple dimensions of the generosity and selectivity of merit-aid programs measure the amount of aid provided to a recipient, the percent of students who are recipients of aid, and the rigor of the program; thus,

\footnotetext{
${ }^{8}$ Dynarski (2004) and Fitzpatrick and Jones (2016) focus on states where at least 30 percent of high school students in the state would be eligible to receive merit aid based on their grades and test scores: Arkansas, Georgia, Mississippi, Florida, New Mexico, Louisiana, South Carolina, Kentucky, Nevada, Michigan, West Virginia, Maryland, South Dakota, Tennessee, Wyoming. Dynarski (2004) includes 13 states while Fitzpatrick and Jones (2016) adds two more recent state programs: South Dakota and Wyoming.

${ }^{9}$ Sjoquist and Winters (2012) define strong merit-aid programs as: Florida, Georgia, Kentucky, Louisiana, Nevada, New Mexico, South Carolina, Tennessee, and West Virginia. They define weak merit-aid programs as: Alaska, Arkansas, California, Delaware, Idaho, Illinois, Maryland, Massachusetts, Michigan, Mississippi, Missouri, Montana, New Jersey, New York, North Dakota, Oklahoma, South Dakota, Utah, Washington, and Wyoming.

${ }^{10}$ The distinctions between these alternate definitions of merit-aid programs and the preferred measures used in this paper are shown in Appendix Table 2.

${ }_{11}$ Each of these two variables are defined as interaction terms with Merit, where the continuous variables are centered on the mean of the sample among states with a merit-aid program in that year (in which Merit =1).

${ }^{12}$ The reference category for these sets of variables are states without a merit-aid program in that year and states without a minimum GPA or standardized test score requirement in that year.
} 
these measures represent the probability that a student qualifies for merit aid and the magnitude of the price reduction.

The identifying variation comes from changes within states over time. Thus, we assume that the introduction of, or changes to, the state merit-aid program did not occur at the same time as other state policies affecting youth labor market outcomes and is not correlated with the unobserved determinants of these outcomes within states over time. A potential concern with our identifying assumption is that states may introduce or change a merit-aid program in response to prior trends in youth labor market indicators within the state or to prior trends in high school performance or college enrollment that also influence youth labor market outcomes. Although it is not possible to test whether our identifying assumption is true, previous research consistently finds evidence to support this assumption (e.g., Fitzpatrick and Jones, 2016). Further, below, we provide robustness checks and falsification tests that provide evidence consistent with the identifying assumption. For example, we find that the primary estimates are similar if we measure the generosity and selectivity of merit-aid programs by the values in the initial year of the program, which suggests that the estimates are not influenced by changes to the design of merit-aid programs in response to trends in economic or educational attainment after the program is introduced. We also find that the primary estimates are similar after controlling for state programs providing need-based aid, suggesting that the estimates reflect the impact of merit-aid programs, instead of other state programs. The results are also robust to restricting the sample to states that have ever introduced a merit-aid program, which minimizes the potential scope of policy endogeneity and compares states that introduced merit-aid programs during different years and with different levels of generosity and selectivity.

\section{Data}

To determine the impact of merit-aid programs on youth labor market outcomes, we examine data from the Current Population Survey (CPS). The CPS is a nationally representative monthly survey of 60,000 households. The survey provides demographic, education, and labor market information for the civilian non-institutional population 16 years and older. For this analysis, the CPS is the most appropriate data source due to the wide range of years available; wide coverage of states; monthly frequency of the data, which allows us, to some extent, to distinguish between the academic year and summer; and large sample size. 
The CPS includes detailed questions on labor market outcomes, including whether the individual is participating in the labor force (LFP), employed, and the actual hours of work in the previous week, if employed. Individuals under age 25 are also asked if they are enrolled in school, independent of their labor market status. Additional individual characteristics include age, race, family income, and gender. When we restrict our attention to individuals within primary families, we are also able to control for the highest level of education of a parent, parent's marital status, birth order, and the number of siblings.

We merge details of the merit aid programs with the CPS based on the state of residence reported that month. Table 1 displays the set of states with merit-aid programs. In addition to a binary variable denoting whether the state has a merit-aid program, we create two measures of the generosity of the program. The first is the maximum amount of aid for all expenses (including tuition, fees, and other expenses) as a percent of the average in-state tuition and fees of 4-year public universities in the state weighted by the enrollment at each university. The maximum potential aid is taken over all merit-aid programs in a state each year, as some states have more than one merit-aid program. The second measure is the percent of in-state college students receiving merit aid, which is defined as the sum of all recipients of merit aid divided by the total number of undergraduate students in a public college for each state in each year. We also create two sets of measures of the selectivity of the state's merit-aid program. We define three binary variables that measure the minimum GPA requirements that determine eligibility: having a minimum GPA requirement of at least 2.5 and less than 3 , at least 3 and less than 3.5, and at least 3.5. We also define a second set of measures that reflect the minimum standardized test score eligibility requirements. We create three binary variables based on required ACT and SAT-equivalent scores: having a minimum ACT requirement of 20 or less, 21 to 27, and at least 28. We convert SAT score requirements to ACT scores using the information provided in Marco, Abdel-fattah, and Baron (1992).

We restrict the sample to ages 16-18 without a high school diploma. We also focus on respondents during the academic year; thus, we exclude June, July, and August from the analysis. ${ }^{13}$ These sample restrictions yield 910,378 observations from 1989 through 2013 . We

\footnotetext{
${ }^{13}$ The CPS reference week occurs in the week containing the $12^{\text {th }}$ day of the month. There are four years in this time period in which the Labor Day weekend falls into the reference week, which increases the likelihood that labor market activity during the reference week reflects summer employment in some states, instead of academic year employment. Because of the differences in the starting and ending times for school years across school districts
} 
restrict the sample to begin in 1989 since we are able to link parental characteristics with respondents' labor market outcomes for individuals in primary families beginning in 1989, which is important for investigating heterogeneity by parents' educational attainment. ${ }^{14}$ Beginning the sample in 1989 is not a significant limitation since only two states offered merit aid then (Illinois and Missouri). For primary families, there are with 783,271 observations.

Table 2 displays the summary statistics of the full sample and of the primary family sample. Overall, 38.5 percent of high school-aged teenagers participated in the labor force during the academic year and 31.4 percent were employed. For those that worked, the average number of hours per week was 17.

Approximately 22 percent of respondents had the potential to receive merit aid. Conditional on a merit-aid program being available in the state when the respondent is 18 years old, the average merit-aid program provides assistance equivalent to approximately 60 percent of in-state tuition and fees and approximately 12 percent of undergraduate students receive aid. Three percent of teenagers, or 13 percent of teenagers in states with a merit-aid program, face a minimum GPA requirement of 2.5 to less than 3.0. Six percent of teenagers, which is 26 percent of teenagers in states with a merit-aid program, have a minimum GPA requirement of 3.0 to less than 3.5. Another three percent of teenagers, or 13 percent in states with merit aid, have a minimum GPA requirement that is greater than or equal to 3.5. Similarly, two percent of teenagers, which is 13 percent of teenagers in states with a merit-aid program, have the potential to receive a merit-aid scholarship that includes a minimum ACT score requirement of 20 or lower. Two percent of youths, which is 11 percent of teenagers in states with a merit-aid program, face a minimum ACT requirement of 21 to 27 . Seven percent of youths, which is 30 percent of teenagers in states with a merit-aid program, face a minimum ACT requirement of 28 or higher. Of the students that have the potential to receive merit aid, slightly more than onethird have a strong merit-aid program available, as classified by Sjoquist and Winters (2012), and nearly half have a broad merit-aid program available, as classified by Dynarski (2004) and Fitzpatrick and Jones (2016).

within states and across years, we are not able to define precisely LFP for students in the summer. Instead, we exclude the months where the regional differences in the start and end dates suggest that there will be a large share of students not in school and focus the analysis on the months that are most likely to define the academic year.

${ }^{14}$ Primary families in this analysis refer to the primary household member and their immediate family members. No subfamilies, related or unrelated, are included in the analysis due to matching issues. 
The characteristics of primary families are very similar to the full sample, except that respondents in the primary family sample are more likely to be white. For the additional variables, over one-fourth of the sample lives in a one-parent household and three-fourths of the sample live in a house owned by a parent. Fifteen percent have a sibling in college and the average birth order is 1.4 .

\section{Results}

\section{a. Labor Force Participation}

Table 3 displays the estimates of the impact of state merit-aid programs on teenage labor force participation during the academic year. The first column includes the estimates from equation (1), which only includes a binary variable indicating whether a state has a merit-aid program. These estimates suggest that a merit-aid program increases labor force participation of teenagers by 1.7 percentage points. The second column includes indicators for whether the state has a strong or weak merit-aid program, as classified by Sjoquist and Winters (2012). Interestingly, these estimates suggest that the result from the first column is driven by states with weak merit-aid programs. The third column includes a binary variable denoting whether the state has a broad merit-aid program, as classified by Dynarski (2004) and Fitzpatrick and Jones (2016). ${ }^{15}$ These estimates suggest that a broad program has little influence on teenage labor force participation.

The fourth column is our preferred specification; it includes estimates from equation (2) that add the measures of the generosity and selectivity of merit-aid programs. These estimates suggest that a merit-aid program with no GPA or test score requirement, which provides the average amount of aid to the average percent of undergraduate students, increases teen labor force participation by 3.2 percentage points. Interestingly, the share of tuition and fees covered and the share of students receiving benefits, which are both measures of the generosity of the program, do not statistically affect the labor supply decision while the measures of selectivity, the GPA and test requirements, do. The more rigorous the GPA requirement, the lower the probability of participating in the labor force. Relative to a state with a merit-aid program without a minimum GPA requirement, a GPA requirement of 3.5 or higher lowers the probability

\footnotetext{
${ }^{15}$ The reference category for states with broad merit-aid programs includes states that do not have a merit-aid program and merit-aid programs in which less than 30 percent of high school students qualify.
} 
of participating in the labor force by over six percentage points. A GPA of 3 to less than 3.5 lowers the probability of participating in the labor force as a teenager by approximately four percentage points, while a relatively low GPA requirement of 2.5 to less than 3 does not statistically alter the labor force participation decision. These results show that a state with a merit-aid program that requires at least a 3.5 GPA reduces teen LFP by 3.6 percentage points relative to a state without a merit-aid program.

The coefficients for test score requirements display a different pattern than the coefficients for GPA requirements. A minimum ACT score requirement between 21 and 27, the middle group in terms of rigor, increases participation in the labor force. A score requirement over 27 decreases LFP by almost 2 percentage points, which is not enough to completely offset the positive effect of having a merit aid program. In combination, a merit-aid program with the most selective thresholds, requiring at least a $3.5 \mathrm{GPA}$ and at least a 28 on the ACT, reduces teen LFP by 5.3 percentage points, relative to a state without a merit-aid program. ${ }^{16}$

The fifth column displays the estimates from equation (2) for the sample of individuals within primary families. These estimates are similar to those in the fourth column, which suggests that the results are robust to restricting the sample to individuals within primary families. Thus, below, we utilize the additional information about parental characteristics in this sample to examine the heterogeneity of the impact of merit-aid programs based on parents' education.

\section{b. Other Labor Market Outcomes}

Table 4 displays the results for employment status, hours worked, hours worked conditional on employment, and two threshold measures of hours. In general, except for the conditional hours of work, these results are similar qualitatively to those for labor force participation, albeit slightly less precisely estimated. A merit aid program with no GPA or standardized test score requirements, with the average amount of aid and percent recipients, leads to an increase in the probability of working and hours worked, while higher GPA requirements work to offset this effect. High school-aged youths in a state that introduces a

\footnotetext{
${ }^{16}$ Eighty percent of youths who reside in a state with a merit-aid program that requires a GPA of at least 3.5 also live in a state that requires an ACT score of at least 28, while the remaining twenty percent reside in a state with a merit-aid program that does not require a minimum ACT score. Thirty-four percent of youths who reside in a state with a merit-aid program that requires an ACT score of at least 28 also reside in a state that requires a GPA of at least 3.5, while the remaining sixty-six percent live in a state that does not require a minimum GPA.
} 
merit-aid program with a minimum GPA requirement of at least 3.5, with the average amount of aid and percent recipients and no standardized test score requirement, are 3 percentage points less likely to be employed, work 0.7 hours less per week, are 3 percentage points less likely to work more than 10 hours per week, and are 2 percentage points less likely to work more than 20 hours per week. Interestingly, a state merit-aid program and the differences in the generosity or selectivity of the program have no statistically significant impact on hours worked conditional on working, except for having the a ACT score requirements between 21 and 27. This result suggests that the influence of merit-aid programs on hours worked is primarily due to the influence on employment.

\section{c. Heterogeneity by Gender and Parent's Education Level}

In addition to examining the intensive margin, we also examine heterogeneity in the impact of merit-aid programs by gender and by parents' educational attainment, as a proxy for students' likelihood of going to college. ${ }^{17}$ Cataldi et al. (2018) find that, among high school students whose parents had not attended college, 72 percent later attended college. In contrast, for high school students whose parents had graduated from college, 93 percent later attended college.

These results, shown in Table 5, provide some interesting insights. In general, females are more responsive to the criteria for the merit aid plans than males. A merit aid program, with the average level of generosity and no GPA or ACT requirements, increases the likelihood of a female participating in the labor force by 4.4 percentage points and a male by 1.9 percentage points. A GPA requirement of over 3.5 lowers the probability of teenage females participating in the labor force by almost 8 percentage points compared to a 6 percentage points decrease for males. A moderate GPA requirement of 3.0 to less than 3.5 does not statistically alter the labor force participation decision of males but lowers female's participation by almost 6 percentage points. Both male and female LFP responds positively to test scores between 21 and 27, but only females have a significant negative response to a merit-aid program that requires at least a score of 28 on the ACT exam, lowering the probability of participating by almost 3 percentage points.

\footnotetext{
${ }^{17}$ Educational attainment, rather than income, is used to stratify the analysis as parental income for families with children approaching college age may be influenced by financial aid requirements.
} 
A merit aid program without GPA and ACT score requirements does not significantly alter the LFP decision of students whose parents have a high school diploma, while it increases the probability of being in the labor force for students whose parents did not complete high school, attended some college, or completed a college degree. All students, regardless of parents' education, are less likely to participate in the labor force when the GPA requirement is 3.5 or higher. High test scores requirements, above a 27, matter more for students with lesseducated parents, relative to students with college-educated parents. These results suggest that although there are some differences in the response of students based on their parent's educational attainment, merit aid requirements influence teen labor force participation across all groups of students. A possible explanation for this result is increased attention to the importance of grades and test scores due to the merit aid program.

\section{d. Robustness}

The results described above pertain to all individuals between the ages of 16 and 18 who have not completed a high school degree. We examine the robustness of these results to alternate definitions of the sample and alternate definitions of the merit-aid variables. These results are shown in Table 6 for LFP. The results are similar to those from our preferred specification, shown in column 4 of Table 3, when we restrict the sample to students currently in high school (thus, excluding dropouts), youths age 17 and 18, and students age 17 and 18 currently in high school. Instead of using time-varying measures of the amount of aid and the percent recipients for each merit-aid program, we examine the robustness of the results to using these measures for the initial year that the program was introduced. As shown in column 4, the results are robust to these alternate measures. As shown in column 5, the results are also robust to defining the generosity of the merit-aid program in terms of the remaining out-of-pocket expenses for recipients, instead of the amount of aid available to recipients. As shown in column 6 , the results are robust to including an additional control variable for whether a state offers need-based aid. Further, as shown in column 7, the results are robust to restricting the sample to states that have ever introduced a merit-aid program.

\section{e. Impact on National Trends}


These results suggest that the characteristics of a state's merit aid plan have the potential to influence the labor-leisure decisions of high school students. Figure 3 simulates what the national labor force participation rates would look like for these high school students under different merit aid plan scenarios: Highly selective (3.5 GPA or higher and greater than a 27 on ACT), least selective (GPA requirement less than 3.0 and ACT score less than 21), and no merit aid plans. In general, the participation rate would be approximately five percent lower if every state had a highly selective plan and approximately four percent higher if every state had the lowest required credentials. However, the actual LFP trend aligns closely with the scenario in which there are no merit aid programs, as the influence of high and low selectivity plans are offsetting. This pattern changed somewhat during the Great Recession, as the responsiveness to the highly selective plans increased. Overall, while merit aid program impact the labor market within states, the effect on the macro-economy is limited.

\section{Conclusion}

Merit-aid programs reduce the price of college attendance and, thus, have the potential to influence students' allocation of time and effort between labor market activities and human capital development. However, what is unique about this price reduction is that it depends upon whether the student exceeds specific educational criteria in high school in order to receive the aid; thus, there is uncertainty about the amount. To understand whether and how these programs might influence youths' labor market activities, we examine the impact of the generosity and selectivity of states' merit-aid programs on a variety of labor market outcomes. Programs with the average level of generosity and no selectivity requirements increase youth LFP. Increases in the generosity of these programs generally has little influence on youth LFP. However, programs that are highly selective, because of GPA or ACT requirements, reduce LFP.

The increase in state merit-aid programs has been occurring during a period in which youth LFP has rapidly fallen and is now at its lowest level in over 50 years. Overall, our results suggest that, while differences in state merit-aid programs influence the labor supply of high school-aged youth, the introduction and expansion of merit-aid programs has not been a cause of this large decline in youth LFP due to the heterogeneity in these state programs. This finding points to the importance of examining the differences across state programs. 


\section{References}

Aaronson, Daniel, Kyung-Hong Park, and Daniel Sullivan. (2006) "The Decline in Teen Labor Force Participation." Economic Perspectives, 2-18.

Baum, Charles L. and Christopher Ruhm. (2016) "The Changing Benefits of Early Work Experience." Southern Economic Journal, 83(2), 343-363.

Canon, Maria, Marianna Kudlyak, and Yang Liu. (2015) "Youth Labor Force Participation Continues to Fall, but It Might Be for a Good Reason." The Regional Economist, 12-13.

Carruthers, Celeste K. and Umut Ozek. (2013) "Losing HOPE: Financial Aid and the Line Between College and Work." National Center for Analysis of Longitudinal Data in Education Research Working Paper.

Castleman, Benjamin L. and Bridget Terry Long. (2013) "Looking Beyond Enrollment: The Causal Effect of Need-Based Grants on College Access, Persistence, and Graduation." NBER Working Paper 19306.

Cataldi, Emily Forrest, Christopher T. Bennett, and Xianglei Chen. (2018) First-Generation Students: College Access, Persistence, and Postbachelor's Outcomes. National Center for Education Statistics. NCES 2018-421.

Cohodes, Sarah R. and Joshua S. Goodman. (2014) "Merit Aid, College Quality, and College Completion: Massachusetts' Adams Scholarship as an In-Kind Subsidy." American Economic Journal: Applied Economics 6(4): 251-285.

Conley, Timothy G. and Christopher R. Taber. (2011) "Inference with 'Difference in Differences' with a Small Number of Policy Changes." Review of Economics and Statistics 93(1): 113-125.

Cornwell, Christopher, David B. Mustard, and Deeepa Sridhar. (2006) “The Enrollment Effects of Merit-Based Financial Aid: Evidence from Georgia's HOPE Program.” Journal of Labor Economics 24(4): 761-786.

Dynarski, Susan. (2000) "Hope for Whom? Financial Aid for the Middle Class and Its Impact on College Attendance.” National Tax Journal 53(3): 629-661.

Dynarski, Susan. (2004) "The New Merit Aid." In College Choices: The Economics of Which College, When College, and How to Pay for It. Caroline M. Hoxby (Ed.) Chicago: University of Chicago Press, p. 63-97.

Eckstein, Zvi, and Kenneth I. Wolpin. (1999). "Why Youths Drop Out of High School: The Impact of Preferences, Opportunities, and Abilities.” Econometrica, 67 (6): 1295-1339.

Fitzpatrick, Maria and Damon Jones. (2012) "Higher Education, Merit-Based Scholarships and Post-Baccalaureate Migration.” NBER Working Paper 18530.

Frisvold, David and Melinda Pitts (2017). "College Attendance and Merit Aid Requirements" Unpublished Manuscript.

Griffith, Amanda L. (2011) "Keeping Up with the Joneses: Institutional Changes Following the Adoption of a Merit Aid Policy." Economics of Education Review 30: 1022-1033.

Hotz, V. Joseph, Lixin Xu, Marta Tienda, Avner Ahituv. (2002). "Are There Returns to the Wages of Young Men from Working While in School?" Review of Economics and Statistics, 84 (2):221-236.

Lee, Chanyoung, and Peter F. Orazem. (2010). "High School Employment, School Performance, and College Entry." Economics of Education Review, 29: 29-39.

Light, Audrey. (2001). "In-School Work Experience and the Returns to Schooling." Journal of Labor Economics, 19 (1): 65-93. 
Long, Bridget Terry. (2004) "How do Financial Aid Policies Affect Colleges? The Institutional Impact of the Georgia HOPE Scholarship.” Journal of Human Resources 39(4): 10451066.

Montmarquette, Claude, Nathalie Viennot-Briot, and Marcel Dagenais. (2007). "Dropout, School Performance, and Working While in School." Review of Economics and Statistics, 89 (4):752-760.

Pallais, Amanda. (2009) "Taking a Chance on College: Is the Tennessee Education Lottery Scholarship Program a Winner?” Journal of Human Resources 44(1): 199-222.

Ruhm, Christopher J. (1997). "Is High School Employment Consumption or Investment?" Journal of Labor Economics, 15 (4): 735-776.

Sabia, Joseph J. (2009). "School-Year Employment and Academic Performance of Young Adolescents." Economics of Education Review, 28 (2): 268-276.

Scott-Clayton, Judith. (2011) "On Money and Motivation: A Quasi-Experimental Analysis of Financial Incentives for College Achievement." Journal of Human Resources 46(3): 614646.

Sjoquist, David L. and John V. Winters. (2012) "State Merit-based Financial Aid Programs and College Attainment.” IZA Discussion Paper No. 6801.

Sjoquist, David L. and John V. Winters. (2015) "The Effect of State Merit-based Financial Aid on the Choice of College Major", Journal of Labor Economics, 2015, 33(4), 973-1006. 
Figure 1

Labor Force Participation Rates Since 1960

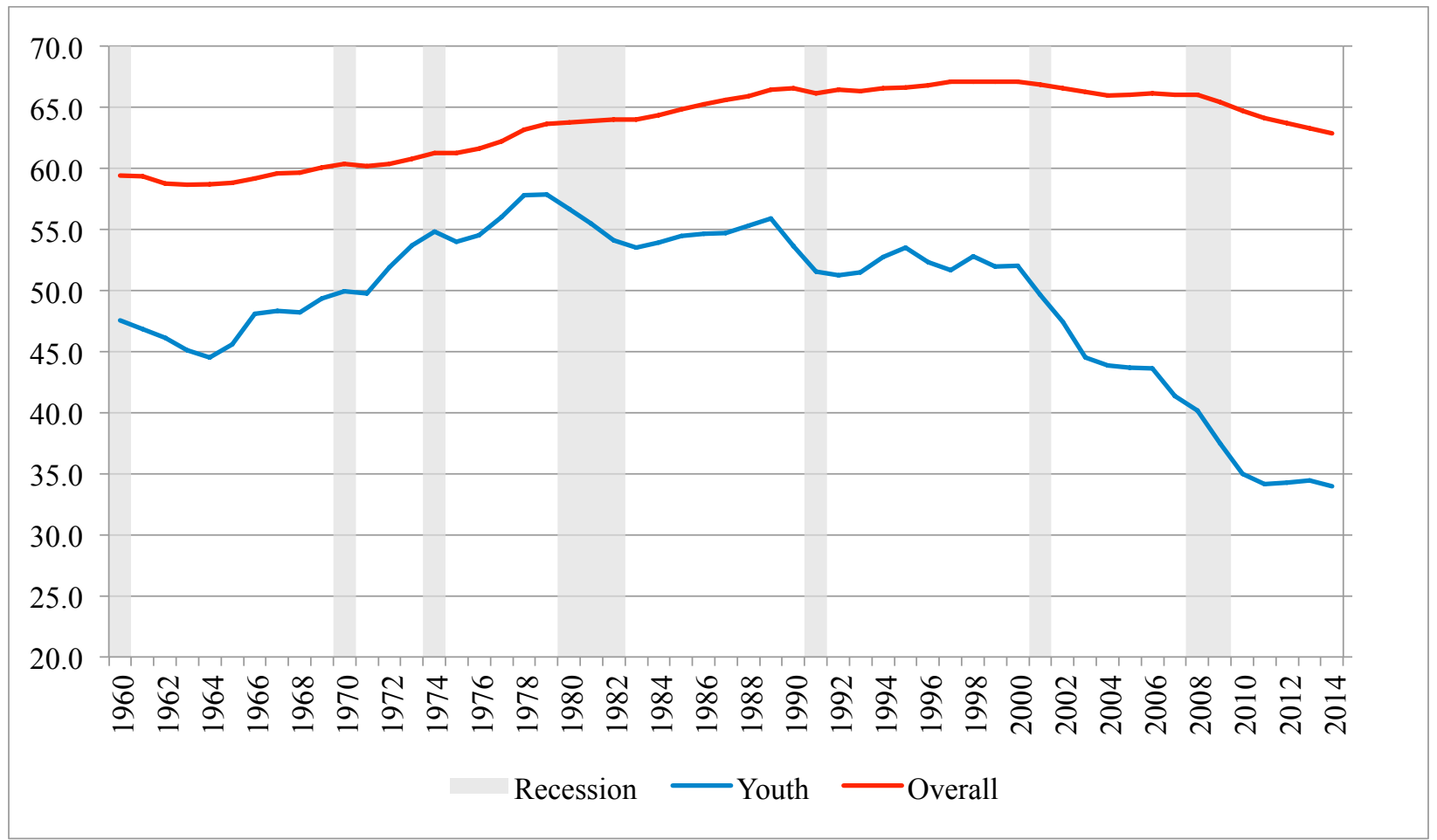

Notes: Youth labor force participation rates refer to individuals ages 16 through 24 . The overall labor force participation rates includes all adults ages 16 and over.

Source: Haver Analytics/Bureau of Labor Statistics 
Figure 2

The Decline in Youth Labor Force Participation and the Increase in State Merit-Aid Programs

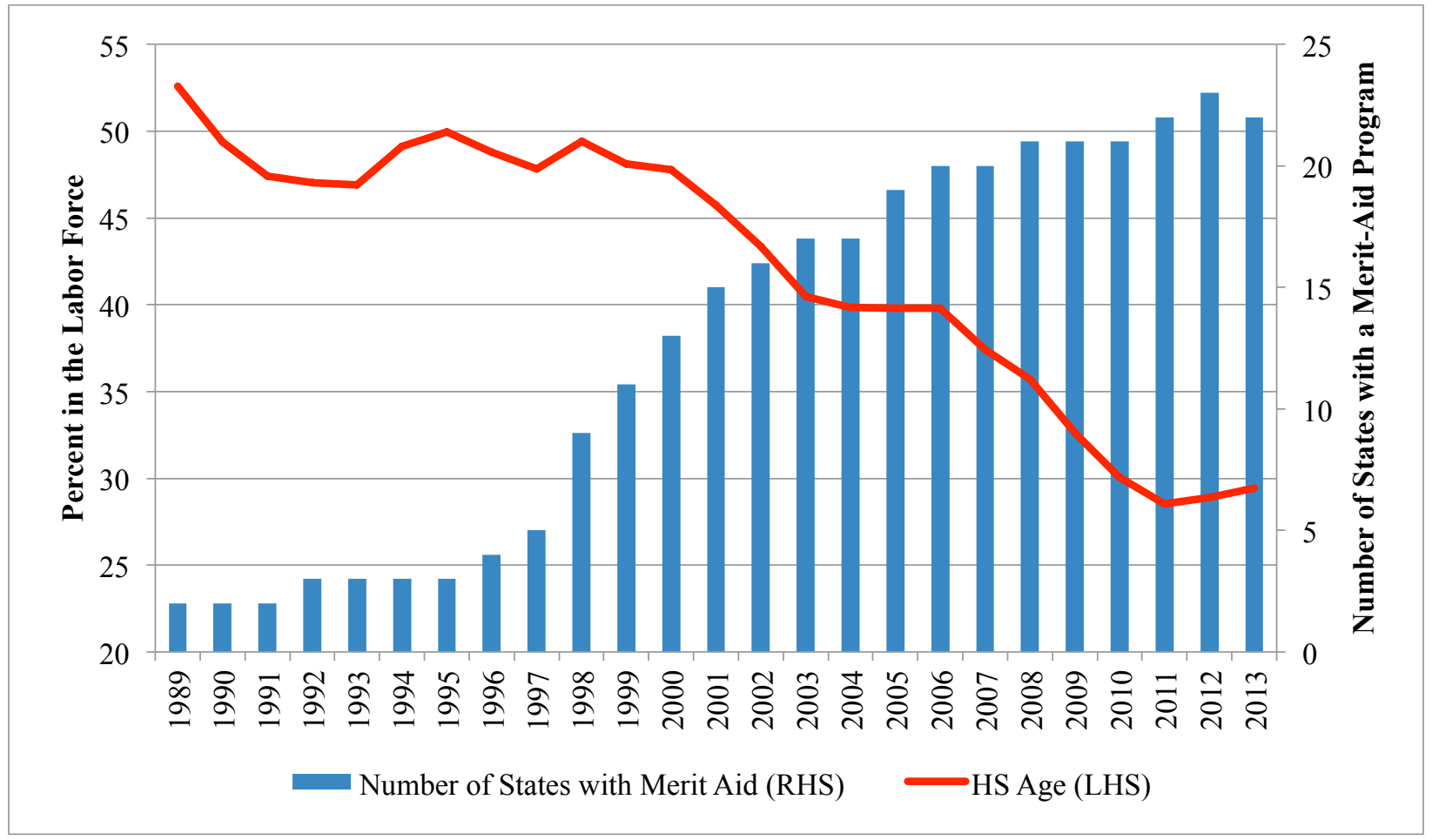

Notes: High school age refers to ages 16 through 18.

Source: Current Population Survey, author's calculations. 
Figure 3

Predicted Labor Force Participation under Different Merit Aid Program Characteristics

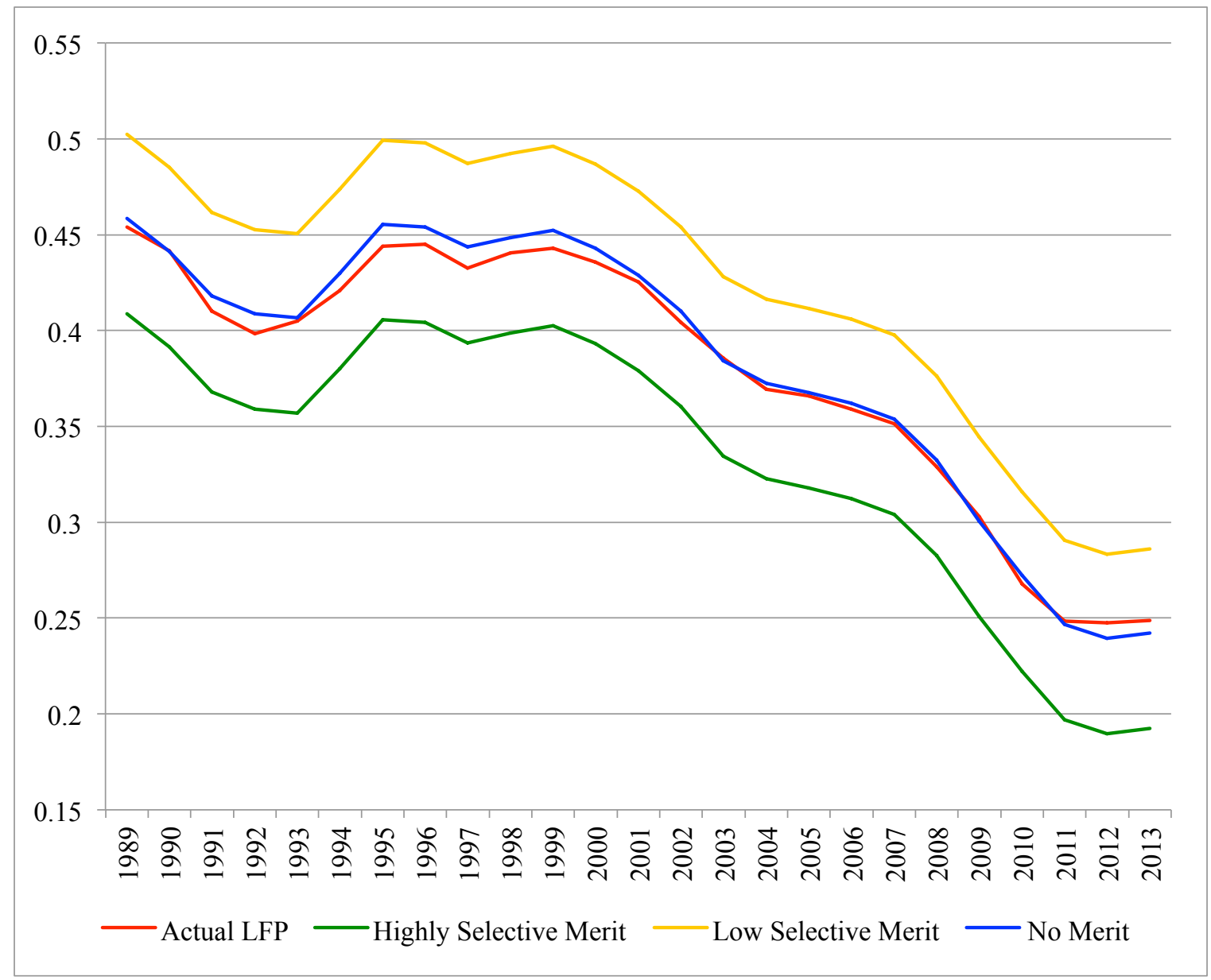

Notes: This figures shows predicted labor force participation rates of teenagers during the academic year. Highly selective merit-aid programs include a minimum GPA of 3.5 or higher and greater than 27 on the ACT exam. Least selective merit-aid programs include a minimum GPA below 3.0 and a minimum ACT score below 21 . 
Table 1: Overview of Merit Aid Programs

\begin{tabular}{|c|c|c|c|c|c|c|}
\hline State & $\begin{array}{l}\text { Start } \\
\text { Year }\end{array}$ & $\begin{array}{l}\text { End } \\
\text { Year }\end{array}$ & $\begin{array}{c}\text { Max Aid } \\
(\%) \\
\end{array}$ & $\begin{array}{l}\text { Students } \\
\text { Receiving } \\
\text { Aid (\%) }\end{array}$ & GPA & ACT Score \\
\hline Alaska & 2000 & & 69.15 & 5.39 & 2.5 & 21 \\
\hline Arkansas & 2011 & & 70.93 & 25.62 & 2.5 & 19 \\
\hline Delaware & 2012 & & 27.03 & 9.91 & 2.75 & \\
\hline Florida & 1998 & & 131.19 & 18.96 & 3.5 & 28 \\
\hline Georgia & 1996 & & 102.27 & 32.20 & 3 & \\
\hline Idaho & 2002 & & 11.40 & 14.14 & 3 & 20 \\
\hline Illinois & 1988 & 2005 & 6.99 & 0.62 & & 30 \\
\hline Kentucky & 2000 & & 48.86 & 32.28 & 2.5 & \\
\hline Louisiana & 1999 & & 121.59 & 22.52 & 2.5 & 20 \\
\hline Massachusetts & 2006 & & 16.86 & 4.74 & & \\
\hline Michigan & 2001 & 2008 & 10.51 & 11.16 & & \\
\hline Mississippi & 1997 & & 62.68 & 23.28 & 2.5 & 15 \\
\hline Missouri & 1988 & & 55.79 & 3.08 & & 30.2 \\
\hline Montana & 2006 & & 34.78 & 1.56 & 3 & 20 \\
\hline Nevada & 2001 & & 64.04 & 19.65 & 3.1 & \\
\hline New Jersey & 1998 & 2006 & 114.52 & 1.46 & & 28 \\
\hline New Mexico & 1998 & & 77.78 & 15.02 & & \\
\hline New York & 1998 & & 29.94 & 1.96 & & \\
\hline North Dakota & 2011 & & 23.01 & 8.07 & 3 & 24 \\
\hline South Carolina & 1999 & & 67.50 & 18.63 & 3 & 23.6 \\
\hline South Dakota & 2005 & & 20.74 & 8.20 & 3 & 24 \\
\hline Tennessee & 2005 & & 86.13 & 25.34 & 3 & 20.8 \\
\hline Utah & 2000 & & 70.89 & 3.09 & 3.3 & \\
\hline West Virginia & 2003 & & 96.02 & 12.76 & 3 & 21.5 \\
\hline Wyoming & 2007 & & 96.20 & 25.38 & 2.5 & 19 \\
\hline
\end{tabular}

Notes: This table provides an overview of all states that implemented a merit-aid program between 1989 and 2013. The Start Year indicates the end date of the first academic year that has students covered by merit aid. Max Aid (\%) refers to the average amount of aid for all expenses as a percent of the average in-state tuition and fees of 4-year public universities. Students Receiving Aid (\%) is the average percent of in-state college students receiving merit aid. Max Aid (\%) and Students Receiving Aid (\%) represents the generosity of state merit aid programs, while GPA and ACT Score represents the selectivity of these programs. The averages of the generosity and selectivity are taken over all programs that a state offers over all years that a program exists for the state between 1989 and 2013. A full description of the programs is available in the appendix. 
Table 2. Descriptive Statistics: 1989-2013

\begin{tabular}{|c|c|c|}
\hline & Full Sample & Primary \\
\hline Variable & $\begin{array}{c}\text { Mean } \\
\text { (Std. Dev.) } \\
\end{array}$ & $\begin{array}{c}\text { Mean } \\
\text { (Std. Dev.) }\end{array}$ \\
\hline \multicolumn{3}{|l|}{ Labor Market Outcomes } \\
\hline Labor Force Participation (School Year) & $\begin{array}{l}0.3846 \\
(0.4865)\end{array}$ & $\begin{array}{c}0.3891 \\
(0.4876)\end{array}$ \\
\hline Employed (School Year) & $\begin{array}{c}0.3142 \\
(0.4642)\end{array}$ & $\begin{array}{c}0.3226 \\
(0.4675)\end{array}$ \\
\hline Hours Worked | Employed (School Year) & $\begin{array}{l}17.0464 \\
(9.8931)\end{array}$ & $\begin{array}{l}16.2619 \\
(9.1895)\end{array}$ \\
\hline \multicolumn{3}{|l|}{ Merit Aid Program } \\
\hline Merit Aid & $\begin{array}{c}0.2190 \\
(0.4135)\end{array}$ & $\begin{array}{c}0.2172 \\
(0.4123)\end{array}$ \\
\hline Maximum Merit Aid (as a $\%$ of Tuition and Fees) & $\begin{array}{c}13.2789 \\
(32.2592)\end{array}$ & $\begin{array}{c}13.0804 \\
(31.9987)\end{array}$ \\
\hline Students receiving merit aid (\%) & $\begin{array}{c}2.5801 \\
(7.0092)\end{array}$ & $\begin{array}{c}2.5232 \\
(6.9229)\end{array}$ \\
\hline \multicolumn{3}{|l|}{ Requirements } \\
\hline \multicolumn{3}{|l|}{ GPA Requirements } \\
\hline $2.5 \leq \mathrm{GPA}<3$ & $\begin{array}{c}0.0289 \\
(0.1677)\end{array}$ & $\begin{array}{c}0.0284 \\
(0.1660)\end{array}$ \\
\hline $3 \leq \mathrm{GPA}<3.5$ & $\begin{array}{c}0.0578 \\
(0.2334)\end{array}$ & $\begin{array}{c}0.0572 \\
(0.2323)\end{array}$ \\
\hline $\mathrm{GPA} \geq 3.5$ & $\begin{array}{c}0.0283 \\
(0.1660)\end{array}$ & $\begin{array}{c}0.0278 \\
(0.1644)\end{array}$ \\
\hline \multicolumn{3}{|l|}{ ACT Score Requirements } \\
\hline Test score $\leq 20$ & $\begin{array}{c}0.0291 \\
(0.1680)\end{array}$ & $\begin{array}{c}0.0287 \\
(0.1670)\end{array}$ \\
\hline $21<$ Test score $\leq 27$ & $\begin{array}{c}0.0246 \\
(0.1548)\end{array}$ & $\begin{array}{c}0.0244 \\
(0.1543)\end{array}$ \\
\hline Test score $\geq 28$ & $\begin{array}{c}0.0667 \\
(0.2493)\end{array}$ & $\begin{array}{c}0.0661 \\
(0.2484)\end{array}$ \\
\hline Strong Program & $\begin{array}{c}0.0823 \\
(0.2748)\end{array}$ & $\begin{array}{c}0.0795 \\
(0.2705)\end{array}$ \\
\hline Broad Program & $\begin{array}{c}0.1069 \\
(0.3090)\end{array}$ & $\begin{array}{c}0.1056 \\
(0.3073)\end{array}$ \\
\hline Merit Aid Program $\mid$ Merit Aid $=1$ & & \\
\hline Maximum Merit Aid (as a $\%$ of Tuition and Fees) & $\begin{array}{c}60.2465 \\
(43.3621)\end{array}$ & $\begin{array}{c}60.2214 \\
(43.3030)\end{array}$ \\
\hline Students receiving merit aid (\%) & $\begin{array}{c}11.7828 \\
(10.7672)\end{array}$ & $\begin{array}{c}11.6165 \\
(10.7247)\end{array}$ \\
\hline
\end{tabular}




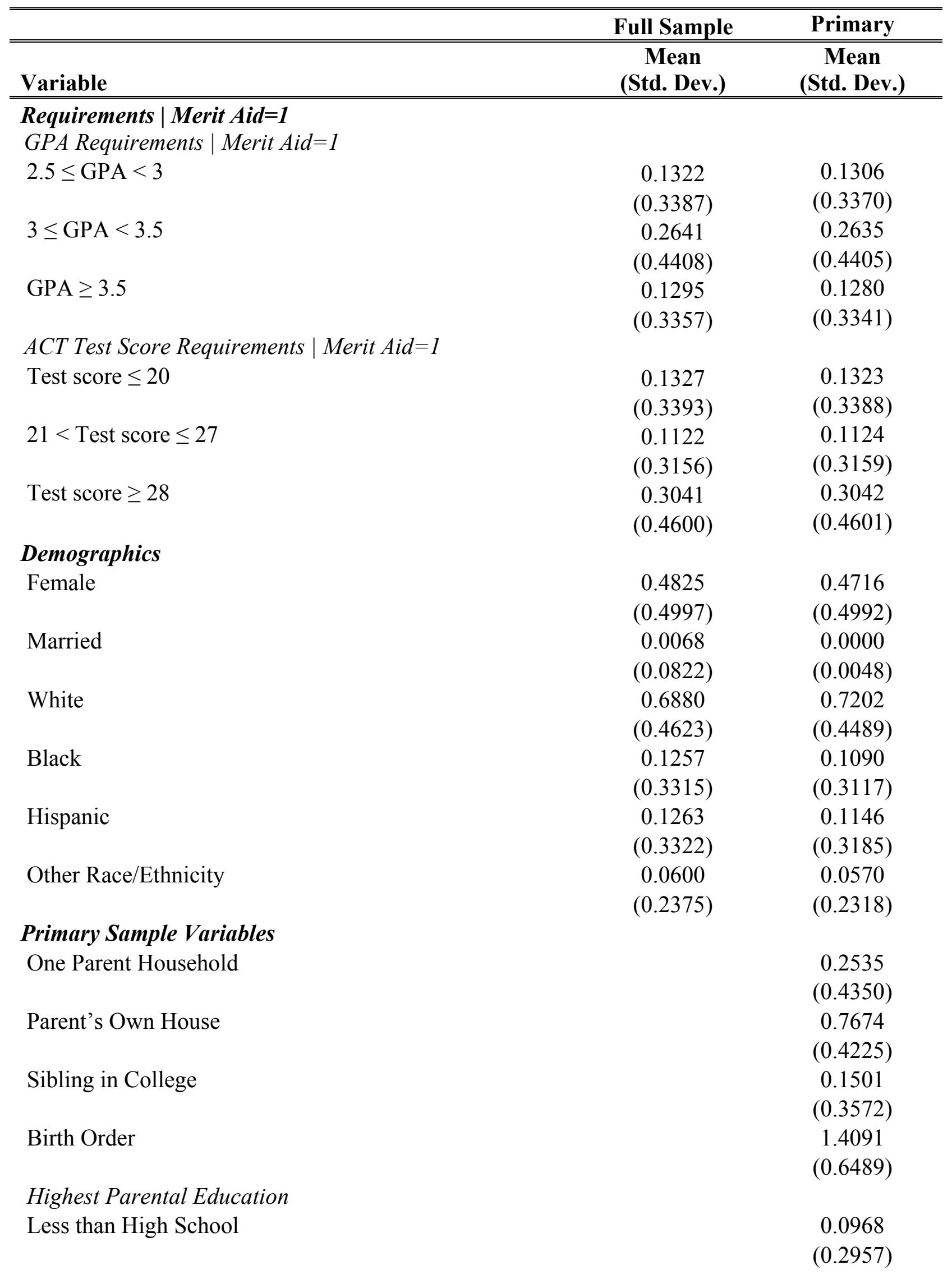




\begin{tabular}{lcc}
\hline \hline & Full Sample & Primary \\
\hline \hline Variable & $\begin{array}{c}\text { Mean } \\
\text { (Std. Dev.) }\end{array}$ & $\begin{array}{c}\text { Mean } \\
\text { (Std. Dev.) }\end{array}$ \\
\hline \hline High School & & 0.2730 \\
& & $(0.4455)$ \\
Some College & & 0.2987 \\
& & $(0.4577)$ \\
College or higher & & 0.3308 \\
Sample Size & 910,378 & $(0.4705)$ \\
\end{tabular}

Notes: Standard deviations in parentheses. The samples include individuals ages 16-18 (highschool aged teenagers) without a high school diploma during the academic year (September through May) between 1989 and 2013. 
Table 3. The Impact of Merit-Aid Programs on Teenage Labor Force Participation

\begin{tabular}{|c|c|c|c|c|c|}
\hline & $(1)$ & $(2)$ & $(3)$ & (4) & $(5)$ \\
\hline & Merit Only & $\begin{array}{c}\text { Strong/Weak } \\
\text { Programs }\end{array}$ & $\begin{array}{c}\text { Broad } \\
\text { Programs }\end{array}$ & $\begin{array}{l}\text { Generosity } \\
\text { and } \\
\text { Selectivity }\end{array}$ & $\begin{array}{c}\text { Generosity and } \\
\text { Selectivity - } \\
\text { Primary Family }\end{array}$ \\
\hline \multicolumn{6}{|l|}{ Merit Aid Program } \\
\hline Merit Aid & $\begin{array}{l}0.0170^{*} \\
(0.0085)\end{array}$ & & & $\begin{array}{c}0.0316^{* *} \\
(0.0121)\end{array}$ & $\begin{array}{c}0.0315 * * \\
(0.0124)\end{array}$ \\
\hline Strong Merit Aid & & $\begin{array}{c}0.0021 \\
(0.0175)\end{array}$ & & & \\
\hline Weak Merit Aid & & $\begin{array}{c}0.0245 * * * \\
(0.0076)\end{array}$ & & & \\
\hline Broad Merit Aid & & & $\begin{array}{c}0.0054 \\
(0.0125)\end{array}$ & & \\
\hline Maximum Aid & & & & 0.0002 & 0.0002 \\
\hline (\% of Tuition and Fees) & & & & $(0.0001)$ & $(0.0001)$ \\
\hline Students receiving & & & & -0.0007 & -0.0008 \\
\hline merit aid (\%) & & & & $(0.0007)$ & $(0.0007)$ \\
\hline \multicolumn{6}{|l|}{ Merit Aid Requirements } \\
\hline \multicolumn{6}{|l|}{ GPA Requirements } \\
\hline $2.5 \leq \mathrm{GPA}<3$ & & & & $\begin{array}{l}-0.0096 \\
(0.0334)\end{array}$ & $\begin{array}{l}-0.0098 \\
(0.0346)\end{array}$ \\
\hline $3 \leq \mathrm{GPA}<3.5$ & & & & $\begin{array}{c}-0.0399 * * \\
(0.0198)\end{array}$ & $\begin{array}{l}-0.0392 * \\
(0.0210)\end{array}$ \\
\hline $\mathrm{GPA} \geq 3.5$ & & & & $\begin{array}{c}-0.0678 * * * \\
(0.0132)\end{array}$ & $\begin{array}{c}-0.0691 * * * \\
(0.0136)\end{array}$ \\
\hline \multicolumn{6}{|l|}{ ACT Score Requirement } \\
\hline Test score $\leq 20$ & & & & $\begin{array}{c}0.0187 \\
(0.0202)\end{array}$ & $\begin{array}{c}0.0175 \\
(0.0209)\end{array}$ \\
\hline $21<$ Test score $\leq 27$ & & & & $\begin{array}{c}0.0442 * * \\
(0.0179)\end{array}$ & $\begin{array}{c}0.0417 * * \\
(0.0198)\end{array}$ \\
\hline Test score $\geq 28$ & & & & $\begin{array}{c}-0.0167 * * \\
(0.0077)\end{array}$ & $\begin{array}{l}-0.0125 \\
(0.0082)\end{array}$ \\
\hline Constant & $\begin{array}{c}0.5344 * * * \\
(0.0138)\end{array}$ & $\begin{array}{c}0.5338 * * * \\
(0.0136)\end{array}$ & $\begin{array}{c}0.5348 * * * \\
(0.0139)\end{array}$ & $\begin{array}{c}0.5337 * * * \\
(0.0131)\end{array}$ & $\begin{array}{c}0.5120 * * * \\
(0.0135)\end{array}$ \\
\hline Observations & 910,378 & 910,378 & 910,378 & 910,378 & 783,271 \\
\hline R-squared & 0.0948 & 0.0948 & 0.0947 & 0.0951 & 0.0955 \\
\hline
\end{tabular}

Notes: Robust standard errors are shown in parentheses and clustered by state. The samples include individuals ages 16-18 (high-school aged teenagers) without a high school diploma during the academic year (September through May) between 1989 and 2013. The last column is restricted to the primary family sample. Additional variables not shown are age, race/ethnicity (black, Hispanic, other race/ethnicity; white is omitted), female, state, year, and month fixed effects. Additional variables not shown for the primary sample regression include whether there is one parent in the household, whether the household owns a house, whether there is a sibling in college, and birth order. All models include year, state, and month fixed effects $* * * \mathrm{p}<0.01, * * \mathrm{p}<0.05, * \mathrm{p}<0.1$ 
Table 4: The Impact of Merit-Aid Programs on Teenage Labor Market Outcomes

\begin{tabular}{|c|c|c|c|c|c|}
\hline & $(1)$ & $(2)$ & (3) & $(4)$ & $(5)$ \\
\hline & Employed & $\begin{array}{c}\text { Hours } \\
\text { Worked } \\
\end{array}$ & $\begin{array}{c}\text { Hours } \\
\text { Worked | } \\
\text { Employed } \\
\end{array}$ & $\begin{array}{c}\text { Work }>10 \\
\text { Hours }\end{array}$ & $\begin{array}{c}\text { Work }>20 \\
\text { Hours }\end{array}$ \\
\hline \multicolumn{6}{|l|}{ Merit Aid Program } \\
\hline Merit Aid & $\begin{array}{c}0.0266^{* *} \\
(0.0118)\end{array}$ & $\begin{array}{l}0.5231 * \\
(0.2621)\end{array}$ & $\begin{array}{c}0.1735 \\
(0.2777)\end{array}$ & $\begin{array}{l}0.0199 * \\
(0.0112)\end{array}$ & $\begin{array}{l}0.0145^{*} \\
(0.0086)\end{array}$ \\
\hline Maximum Aid & $0.0002 *$ & 0.0041 & -0.0011 & 0.0002 & 0.0001 \\
\hline (\% of Tuition and Fees) & $(0.0001)$ & $(0.0034)$ & $(0.0035)$ & $(0.0001)$ & $(0.0001)$ \\
\hline $\begin{array}{l}\text { Students receiving merit aid } \\
(\%)\end{array}$ & $\begin{array}{l}-0.0004 \\
(0.0007)\end{array}$ & $\begin{array}{l}-0.0062 \\
(0.0185)\end{array}$ & $\begin{array}{c}0.0139 \\
(0.0171)\end{array}$ & $\begin{array}{l}-0.0002 \\
(0.0007)\end{array}$ & $\begin{array}{l}-0.0000 \\
(0.0006)\end{array}$ \\
\hline \multicolumn{6}{|l|}{ Merit Aid Requirements } \\
\hline $2.5 \leq \mathrm{GPA}<3$ & $\begin{array}{l}-0.0174 \\
(0.0301)\end{array}$ & $\begin{array}{l}-0.2818 \\
(0.6980)\end{array}$ & $\begin{array}{c}0.4527 \\
(0.6355)\end{array}$ & $\begin{array}{l}-0.0128 \\
(0.0301)\end{array}$ & $\begin{array}{l}-0.0075 \\
(0.0218)\end{array}$ \\
\hline $3 \leq \mathrm{GPA}<3.5$ & $\begin{array}{l}-0.0380 * \\
(0.0195)\end{array}$ & $\begin{array}{l}-0.7896^{*} \\
(0.4479)\end{array}$ & $\begin{array}{l}-0.1892 \\
(0.4822)\end{array}$ & $\begin{array}{l}-0.0344 * \\
(0.0197)\end{array}$ & $\begin{array}{l}-0.0202 \\
(0.0155)\end{array}$ \\
\hline GPA $\geq 3.5$ & $\begin{array}{c}-0.0568 * * * \\
(0.0109)\end{array}$ & $\begin{array}{c}-1.1969 * * * \\
(0.3120)\end{array}$ & $\begin{array}{l}-0.2664 \\
(0.4490)\end{array}$ & $\begin{array}{c}-0.0501 * * * \\
(0.0118)\end{array}$ & $\begin{array}{c}-0.0337 * * * \\
(0.0095)\end{array}$ \\
\hline ACT Score Requirement & & & & & \\
\hline Test score $\leq 20$ & $\begin{array}{c}0.0283 \\
(0.0187)\end{array}$ & $\begin{array}{c}0.6170 \\
(0.4511)\end{array}$ & $\begin{array}{c}0.3587 \\
(0.4607)\end{array}$ & $\begin{array}{c}0.0308 \\
(0.0198)\end{array}$ & $\begin{array}{c}0.0159 \\
(0.0137)\end{array}$ \\
\hline $21<$ Test score $\leq 27$ & $\begin{array}{r}0.0443 * * \\
(0.0190)\end{array}$ & $\begin{array}{r}0.9317 * * \\
(0.4258)\end{array}$ & $\begin{array}{c}0.8191 * * \\
(0.4015)\end{array}$ & $\begin{array}{c}0.0457 * * \\
(0.0190)\end{array}$ & $\begin{array}{l}0.0253 * \\
(0.0137)\end{array}$ \\
\hline Test score $\geq 28$ & $\begin{array}{l}-0.0092 \\
(0.0062)\end{array}$ & $\begin{array}{l}-0.1695 \\
(0.1667)\end{array}$ & $\begin{array}{c}0.3903 \\
(0.2528)\end{array}$ & $\begin{array}{l}-0.0039 \\
(0.0063)\end{array}$ & $\begin{array}{l}-0.0065 \\
(0.0059)\end{array}$ \\
\hline Constant & $\begin{array}{c}0.3940 * * * \\
(0.0116)\end{array}$ & $\begin{array}{c}8.8342 * * * \\
(0.2454)\end{array}$ & $\begin{array}{c}23.9557 * * * \\
(0.3374)\end{array}$ & $\begin{array}{c}0.3351 * * * \\
(0.0102)\end{array}$ & $\begin{array}{c}0.2323 * * * \\
(0.0066)\end{array}$ \\
\hline Observations & 910,378 & 900,086 & 275,781 & 900,086 & 900,086 \\
\hline R-squared & 0.1012 & 0.0854 & 0.1381 & 0.0805 & 0.0536 \\
\hline
\end{tabular}

Notes: See notes on Table 3. ${ }^{* * *} \mathrm{p}<0.01,{ }^{* *} \mathrm{p}<0.05,{ }^{*} \mathrm{p}<0.1$ 
Table 5: Heterogeneity in the Impact of Merit-Aid Programs on Teenage Labor Force Participation by Parents' Education

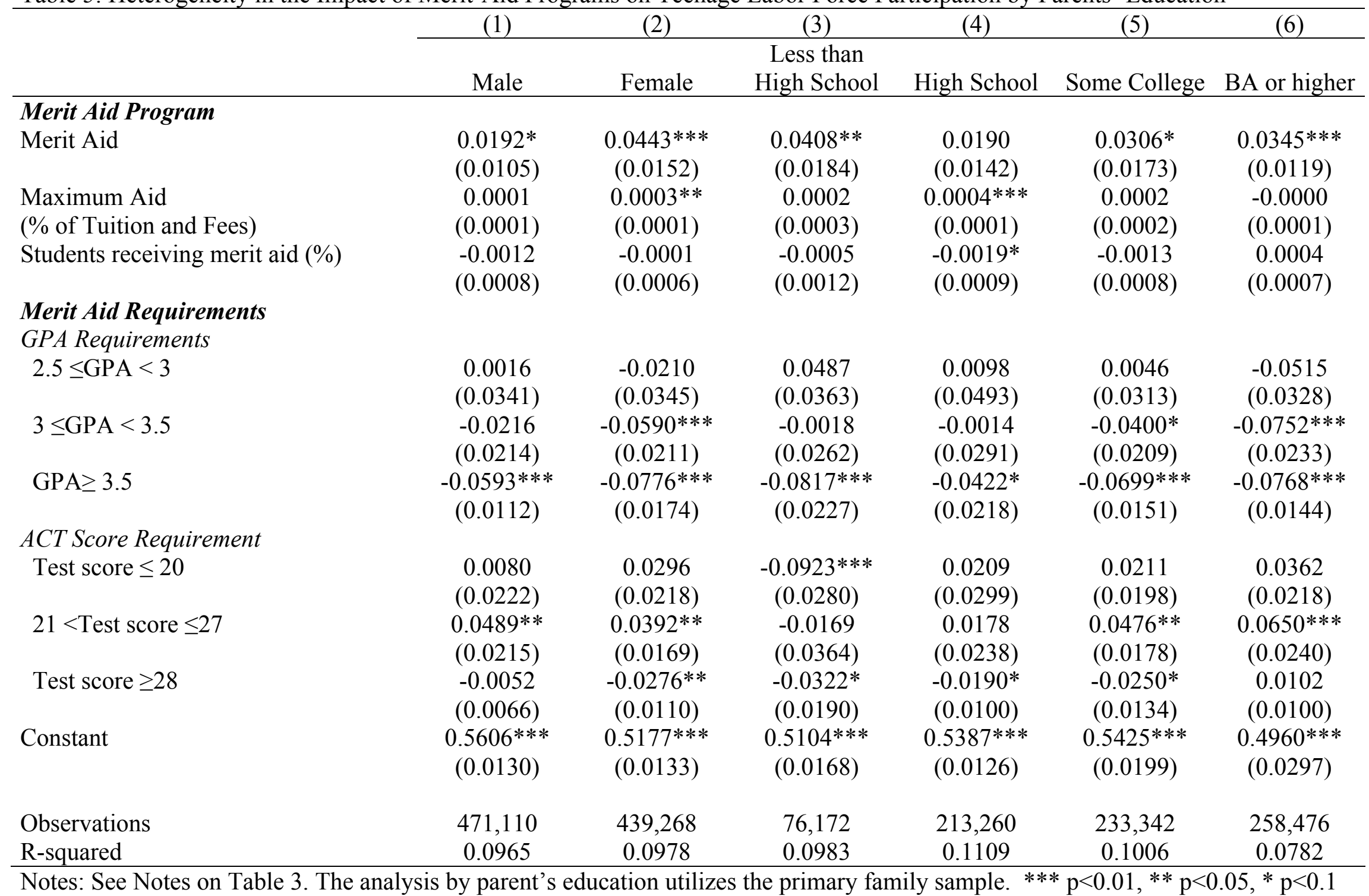


Table 6

Robustness Checks- Labor Force Participation

\begin{tabular}{|c|c|c|c|c|c|c|c|}
\hline & In HS & Age $17-18$ & $\begin{array}{c}\text { Age } 17-18 \text { in } \\
\text { HS }\end{array}$ & $\begin{array}{c}\text { (4) } \\
\text { Aid as a } \\
\text { Share of } \\
\text { Initial } \\
\text { Tuition and } \\
\text { Fees }\end{array}$ & Total Cost & $\begin{array}{c}\text { Includes } \\
\text { Need Based } \\
\text { Merit }\end{array}$ & $\begin{array}{c}(7) \\
\text { States with a } \\
\text { Merit } \\
\text { Program in } \\
\text { any year }\end{array}$ \\
\hline \multicolumn{8}{|l|}{ Merit Aid Program } \\
\hline Merit Aid & $\begin{array}{l}0.0308 * * \\
(0.0123)\end{array}$ & $\begin{array}{l}0.0316 * * * \\
(0.0109)\end{array}$ & $\begin{array}{l}0.0319 * * * \\
(0.0117)\end{array}$ & $\begin{array}{c}0.0263 * * \\
(0.0122)\end{array}$ & $\begin{array}{c}0.0285^{* *} \\
(0.0119)\end{array}$ & $\begin{array}{l}0.0309 * * \\
(0.0121)\end{array}$ & $\begin{array}{c}0.0322 * * \\
(0.0123)\end{array}$ \\
\hline $\begin{array}{l}\text { Maximum Aid } \\
\text { (\% of Tuition and Fees) }\end{array}$ & $\begin{array}{c}0.0002 \\
(0.0001)\end{array}$ & $\begin{array}{c}0.0002 \\
(0.0002)\end{array}$ & $\begin{array}{c}0.0002 \\
(0.0002)\end{array}$ & & & $\begin{array}{c}0.0002 \\
(0.0001)\end{array}$ & $\begin{array}{c}0.0002 \\
(0.0001)\end{array}$ \\
\hline $\begin{array}{l}\text { Students receiving merit } \\
\text { aid }(\%)\end{array}$ & $\begin{array}{l}-0.0006 \\
(0.0007)\end{array}$ & $\begin{array}{l}-0.0006 \\
(0.0009)\end{array}$ & $\begin{array}{l}-0.0003 \\
(0.0009)\end{array}$ & & & $\begin{array}{l}-0.0007 \\
(0.0007)\end{array}$ & $\begin{array}{l}-0.0006 \\
(0.0006)\end{array}$ \\
\hline \multicolumn{8}{|l|}{ Merit Aid Requirements } \\
\hline $2.5 \leq \mathrm{GPA}<3$ & $\begin{array}{l}-0.0122 \\
(0.0335)\end{array}$ & $\begin{array}{l}-0.0179 \\
(0.0367)\end{array}$ & $\begin{array}{l}-0.0263 \\
(0.0380)\end{array}$ & $\begin{array}{l}-0.0175 \\
(0.0349)\end{array}$ & $\begin{array}{l}-0.0093 \\
(0.0334)\end{array}$ & $\begin{array}{l}-0.0094 \\
(0.0334)\end{array}$ & $\begin{array}{l}-0.0069 \\
(0.0329)\end{array}$ \\
\hline $3 \leq \mathrm{GPA}<3.5$ & $\begin{array}{l}-0.0391 * \\
(0.0222)\end{array}$ & $\begin{array}{l}-0.0419 * * \\
(0.0206)\end{array}$ & $\begin{array}{l}-0.0410 \\
(0.0249)\end{array}$ & $\begin{array}{c}-0.0447 * * \\
(0.0211)\end{array}$ & $\begin{array}{l}-0.0389^{*} \\
(0.0204)\end{array}$ & $\begin{array}{c}-0.0400 * * \\
(0.0198)\end{array}$ & $\begin{array}{l}-0.0363^{*} \\
(0.0199)\end{array}$ \\
\hline $\mathrm{GPA} \geq 3.5$ & $\begin{array}{c}-0.0687 * * * \\
(0.0144)\end{array}$ & $\begin{array}{c}-0.0780 * * * \\
(0.0171)\end{array}$ & $\begin{array}{c}-0.0817 * * * \\
(0.0206)\end{array}$ & $\begin{array}{c}-0.0661^{* * *} \\
(0.0111)\end{array}$ & $\begin{array}{l}-0.0589 * * * \\
(0.0098)\end{array}$ & $\begin{array}{c}-0.0679 * * * \\
(0.0131)\end{array}$ & $\begin{array}{c}-0.0636^{* * *} \\
(0.0137)\end{array}$ \\
\hline \multicolumn{8}{|l|}{ ACT Score Requirements } \\
\hline Test score $\leq 20$ & $\begin{array}{c}0.0166 \\
(0.0213)\end{array}$ & $\begin{array}{c}0.0262 \\
(0.0245)\end{array}$ & $\begin{array}{c}0.0255 \\
(0.0267)\end{array}$ & $\begin{array}{c}0.0226 \\
(0.0211)\end{array}$ & $\begin{array}{c}0.0184 \\
(0.0199)\end{array}$ & $\begin{array}{c}0.0186 \\
(0.0203)\end{array}$ & $\begin{array}{c}0.0177 \\
(0.0198)\end{array}$ \\
\hline $21<$ Test score $\leq 27$ & $\begin{array}{c}0.0431^{* *} \\
(0.0198)\end{array}$ & $\begin{array}{l}0.0467 * * \\
(0.0184)\end{array}$ & $\begin{array}{l}0.0445^{*} \\
(0.0222)\end{array}$ & $\begin{array}{c}0.0497 * * \\
(0.0191)\end{array}$ & $\begin{array}{l}0.0422 * * \\
(0.0183)\end{array}$ & $\begin{array}{c}0.0445 * * \\
(0.0179)\end{array}$ & $\begin{array}{c}0.0433 * * \\
(0.0175)\end{array}$ \\
\hline Test score $\geq 28$ & $\begin{array}{l}-0.0115 \\
(0.0081)\end{array}$ & $\begin{array}{l}-0.0179^{*} \\
(0.0095)\end{array}$ & $\begin{array}{l}-0.0104 \\
(0.0109)\end{array}$ & $\begin{array}{c}-0.0199 * * \\
(0.0082)\end{array}$ & $\begin{array}{c}-0.0171 * * \\
(0.0069)\end{array}$ & $\begin{array}{c}-0.0165 * * \\
(0.0077)\end{array}$ & $\begin{array}{c}-0.0199 * * * \\
(0.0069)\end{array}$ \\
\hline Initial year generosity (\%) & & & & $\begin{array}{l}0.0002 * \\
(0.0001)\end{array}$ & & & \\
\hline
\end{tabular}


Maximum Aid (\% of Total

Cost)

Need-based Aid

Constant

Observations

R-squared

Notes: See notes on Table 3. ${ }^{* * *} \mathrm{p}<0.01,{ }^{* *} \mathrm{p}<0.05,{ }^{*} \mathrm{p}<0.1$

$-0.0006 \quad-0.0006$

\begin{tabular}{ccccccc} 
& \multicolumn{9}{c}{$(0.0006)$} & $(0.0007)$ & 0.0004 \\
& & & & $(0.0003)$ \\
$0.4695 * * *$ & $0.4476 * * *$ & $0.4147 * * *$ & $0.5337 * * *$ & $0.5336 * * *$ & $0.5338 * * *$ & $0.5067 * * *$ \\
$(0.0110)$ & $(0.0114)$ & $(0.0112)$ & $(0.0131)$ & $(0.0131)$ & $(0.0130)$ & $(0.0107)$
\end{tabular}

$836,954 \quad 546,358 \quad 483,960$

910,378

910,378

$910,378 \quad 427,428$

0.0838

0.0951

0.0951

0.0951 